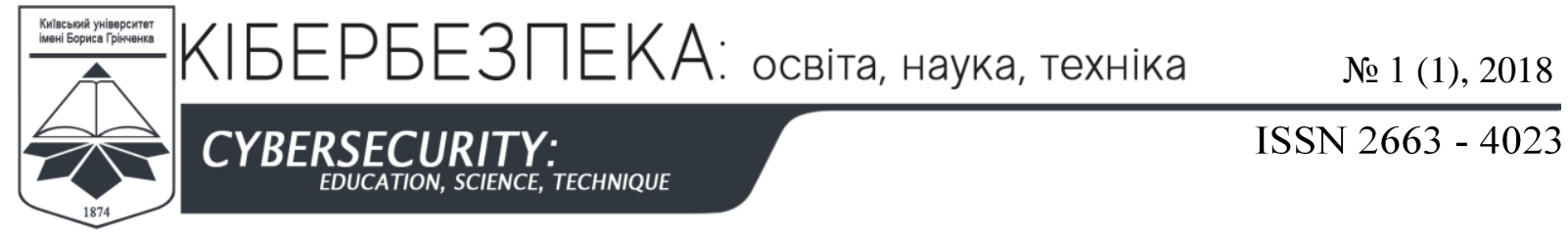

UDC 373.5:53

Dmytro M. Bodnenko

Associate Professor of the Department of Computer Science and Mathematics

Borys Grinchenko Kyiv University, Kyiv, Ukraine

OrcID: 0000-0001-9303-6587

d.bodnenko@kubg.edu.ua

Nykyta V. Ostapenko

Postgraduate of the Department of Computer Science and Mathematics

Borys Grinchenko Kyiv University, Kyiv, Ukraine

OrcID: 0000-0002-4954-8179

m.oostapenko@kubg.edu.ua

\title{
APPLICATION OF CLOUD-BASED LEARNING TECHNOLOGIES IN THE ORGANIZATION STUDENTS' RESEARCH WORK
}

\begin{abstract}
The principal aim of research is to develop a mechanism for the organization of research work of students toward mastery of ICT literacy. In the article it has been formed the model of students' research work organization in the learning process of informatics disciplines; produced the algorithm of cloud-based learning technologies application in the organization of history students' research work; described recommendations for the structure and the content of e-learning materials in the study of cloud-based learning technologies (as a part of the training course in LMS Moodle). The several recommendations can be made on the basis of performed experience analysis of implementing a cloud oriented technologies of Informatics disciplines among the different specialties. It is advisable to use the model-table "Using a cloud oriented technologies of teaching", with appropriate adaptation to scientific-pedagogical and logistical capacity of a particular educational institution (specific structural unit or Department). The introduction of the designated model promotes: productive activity of students; autonomy of learning and the maximum approximation of the accumulated experience to the requirements of the labour market; the formation of an active research position of the project participants; the formation of students " critical thinking by phased activation of the operations of thinking. Using the model need to be creative in overcoming some negative aspects: to develop the motivational aspect of attracting students to research activities; to form the definition of future student's research activities; to maximize the interaction of science with the educational process and with the requirements of the labour market; to overcome the stereotype that not all students should be involved in scientific work.
\end{abstract}

Keywords: cloud-based learning technologies; cloud service; e-learning materials; research-based study; ICT in education; didactics; Competence Formation Process; Information Communication Technology; Teaching Methodology.

\section{INTRODUCTION}

The analysis of social and economic changes shows that Ukraine is undergoing constant restructuring of political, economic and social spheres, which models national priorities and influences on the innovative development of education. One of perspective decisions of the outlined problem, according to the experience of developed countries, is building up of innovative school on principles of cloud-based learning technologies introduction in an educational process. 


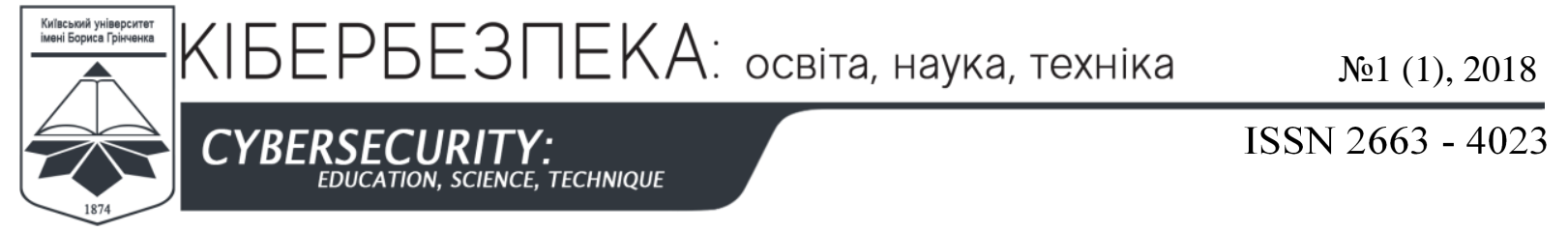

The problem of the implementation of cloud-based learning technologies in realization of bachelor program, currently becomes relevant due to realization of the Law on Higher Education (2014) and the Decree of the President of Ukraine on the "National Strategy for the Development of Education in Ukraine for the period till 2021" (Strategy of 25.06.2013 № 344/2013)

Together with the analysis of cloud-based learning technologies application in educational process in course of informatics, appears another topical problem the forecasting further strategy and the creation and use of these technologies at training of history students. The research work of history students in a higher educational establishment, which is carried out in the form of individual research work or in form of different level of qualifying works, it is possible to observe as the adjusted mechanism, which aims to ensure compliance of the outlined function, it is research-based study.

Task of research: to establish a system of support of students' scientific-research work to master ICT literacy.

\section{MAIN PROBLEM SOLUTION}

\subsection{THE SYSTEM OF ENSURING OF HISTORY STUDENTS' RESEARCH WORK TOWARD MASTERING ICT LITERACY}

Carrying out the experiment with the use of network services and technologies in the course of informatics' disciplines, we have chosen, as the basis, the task of implementing ICT in higher education.

Education of Ukraine is oriented on the European standards, and now it appeared before the necessity of transition from the use of traditional forms and methods of education to implementation of new technologies in education. This is motivated by the fact, that the bulk of the students do not have time to learn the course during lectures and seminars, which are allotted in the curriculum. The increase of independent and individual part of work of students requires from a teacher the implementation of new learning technologies for mastering the required amount of information.

The carried out internet questioning among teachers of educational institutions and Internet users indicates a growing number of students who use e-learning technologies (http://www.voxru.net/arc/internet/interobraz2.html). The analysis of learning organization on research basis, in higher educational establishments of Ukraine gives grounds to assert that the introduction of new paradigm (for the Ukrainian educational space) in the educational process has fragmentary, spontaneous character mostly.

Thereby emphasizing the need of implementation of interdisciplinary connections based on information and communications technologies.

A lot of psycho educational, technical and methodical literature were analyzed with the aim to highlight the outlined problem [2;5;9].

The strategic goal of implementing the cloud-based learning technologies in course of informatics' disciplines is to expand the informative space and also for realization of different principles of learning.

The tactical aim of broader adoption of cloud-based ICT for teaching and learning is the further improvement of use of modern information and communications technologies and teaching tools. 


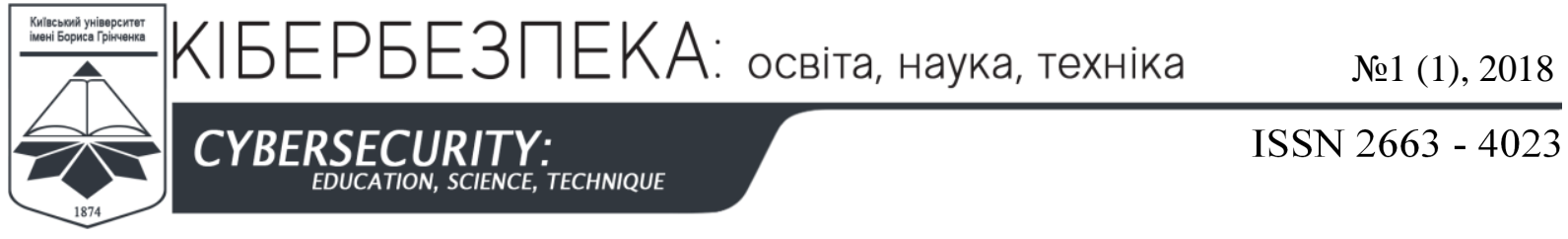

The tactical and strategic goal is the improvement of academics' competence in sphere of ICT [1]. The key components of academics' ICT competence are the ability to use digital technologies, tools and/or communications networks for the provision of educational services (this includes network services and cloud-based technology).

Use of cloud-based technologies in teaching subjects in course of computer science requires special and diligent teacher training. In the conditions of students' research work implementing in the educational process, teacher (tutor) coordinates the learning process; activates the developmental potential of education; defines educational goals of high cognitive level; builds dialogical communication with students.

Didactic support of research-based learning involves extensive use of traditional teaching forms, there are lectures, seminars, consultations, independent work. The introduction of cloud-based technologies in the educational process involves the use of active methods such as business games, trainings, group discussions, individual training, etc. The choice of particular learning technology for each specialty and its detailing regarding discipline carries out at the level of departments and specialties.

The investigation of students' research work organization in course of informatics was carried out in three stages, they are:

The first stage (2008-2010 academic years) - students' research work was organized within limits of the scientific group "The use of ICT in education".

The second stage (2010-1012 academic years) - students' research work was organized within limits of the independent work in course of informatics, in module which calls "Network technologies in the learning process".

The third stage (2013-2018 academic years) - students' research work was organized with a combination of scientific group and project-oriented independent work of academic groups towards "Cloud-based technology in the educational process".

The model-table "The organization of students' research work in course of informatics' disciplines" was formed for convenience (see the Table 1). In this table in the column "Term", we give two types of the organization of students' research work; the first one is within limits of independent work in course of informatics' disciplines (The quantity of ECTS-credits for discipline correspond to 2-4); the second one type of organization of students' research work is within limits of scientific group (the plan provides for 10 meetings for academic year, and the duration of meeting varies from 2 to 4 academic hours).

Table 1

The model-table

"The organization of students' research work in course of informatics' disciplines"

\begin{tabular}{|c|c|c|c|c|}
\hline \multirow[b]{2}{*}{ Stage } & \multirow{2}{*}{$\begin{array}{c}\text { Name of the } \\
\text { stage }\end{array}$} & \multirow[t]{2}{*}{ Activity } & \multicolumn{2}{|c|}{ Term } \\
\hline & & & $\begin{array}{l}\text { Within } \\
\text { limits of } \\
\text { subject } \\
\text { matter }\end{array}$ & $\begin{array}{l}\text { Within } \\
\text { limits of } \\
\text { scientific } \\
\text { group }\end{array}$ \\
\hline I. & $\begin{array}{l}\text { Uniting into } \\
\text { the small } \\
\text { groups }\end{array}$ & $\begin{array}{l}\text { Uniting into the small groups (3-5 } \\
\text { persons), determination of project } \\
\text { manager, distribution of duties }\end{array}$ & $\begin{array}{l}\text { The first } \\
\text { lesson }\end{array}$ & $\begin{array}{l}1^{\text {st }} \text { meeting } \\
\text { of the } \\
\text { scientific } \\
\text { group }\end{array}$ \\
\hline II. & Determination & Determination of cloud & The second & $2^{\text {nd }}$ meeting \\
\hline
\end{tabular}




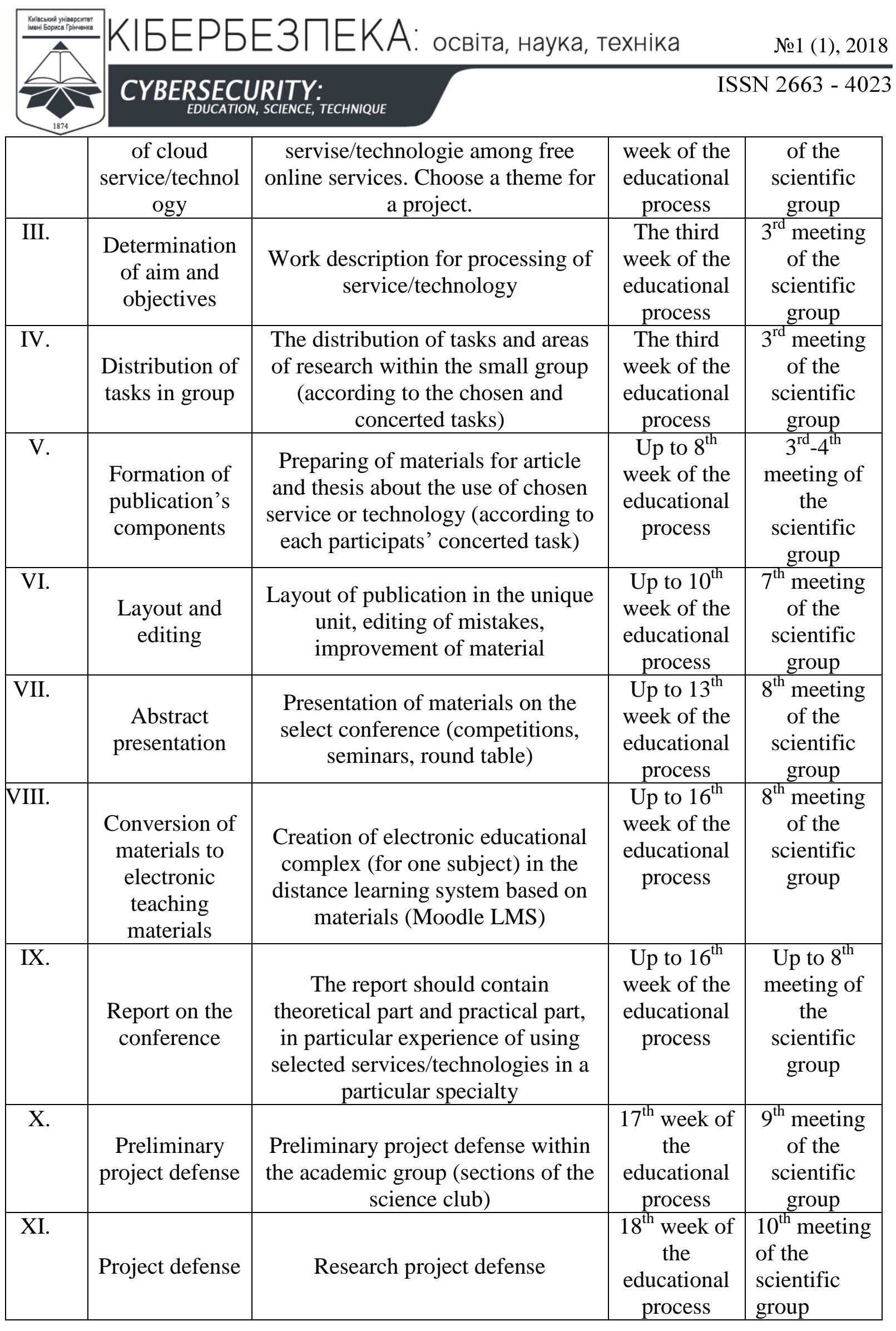

Outlined model-table based on results of activity of science club "The use of ICT in education" [12], which was founded in Borys Grinchenko Kyiv University in 2008. The results of activity of science club were publications in professional journals and presentations 


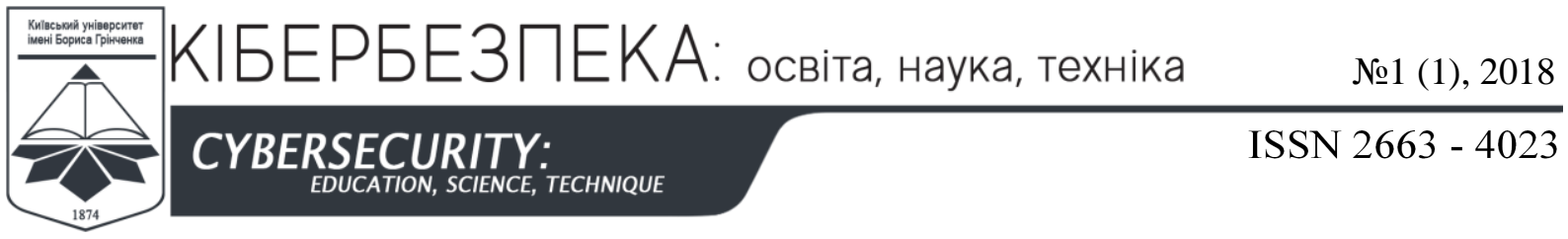

at conferences at various levels. Only certain high-level achievements were recommended to press. Number of printed material ranged from 3-7 publications per year. Main principles and results of the scientific research group were reported and discussed at international scientific conferences: The innovative scientific technology: advanced world experience (Kirovograd, 2012); The professionalism of the teacher in the context of Ukraine's European choice: the quality of education - the foundation of competitiveness of the future expert (Yalta, 2011, 2012); National survey of young researchers in the context of modern science (Kyiv, 2010, 2011); Information Technology (Kyiv, 2014); scientific and methodical seminars of Department of Information Technology and Mathematical Sciences Borys Grinchenko Kyiv University (2008-2018). Selected works has been published in professional journals.

According to a new paradigm of education which is related to the Law on Higher Education (2014) and also related to the formation of the XXI century skills for future graduates from the university, the prospect of further approbation of outlined model is preparation of students' scientific works to participate in international projects

\section{THE CONCLUSION AND WAYS OF FURTHER RESEARCHES}

The model-table "The organization of students' research work in course of informatics' disciplines" was formed. The model consists of the following components: Uniting into the small groups; Determination of cloud service/technology; Determination of goal and object; Distribution of tasks in group; Formation publication's components; Layout and editing; Abstract presentation; Conversion of materials to electronic teaching materials; Report on the conference; Preliminary project defense; Project defense. Each stage has a specific deadline and aims to use cloud-based learning technology on a research basis.

Prospects for further research are seen in the improvement of the model of "the Organization of scientific-research work of students in the learning process of the information disciplines" and detailing the specifics of its use in the training of students of humanitarian specialties.

\section{REFERENCES}

[1] D. M. Bodnenko, "Cloud Oriented Technologies as a Factor of Research-Based Training," Information Technologies and Learning Tools, vol. 48, no. 4, pp. 122-139, 2015.

[2] A. Cimer and M. Timucin, "Content of an In-Service Training to Develop and Assess Activities Minding Critical Thinking," in World Conference on Learning, Teaching and Administration, vol. 9, p. 5, 2010.

[3] G. A. Ferrer and A. Garcia-Barrera, "Evaluation of the Effectiveness of Flipped Classroom Videos," in 8th International Technology, Education and Development Conference (INTED), Valencia, Spain, pp. 2608-2613, 2014.

[4] D. F. Halpern, "Teaching Critical Thinking for Transfer Across Domains - Dispositions, Skills, Structure Training, and Metacognitive Monitoring," American Psychologist, vol. 53, no. 4, pp. 449-455, Apr. 1998.

[5] G. J. Hwang and C. H. Chen, "Influences of an Inquiry-Based Ubiquitous Gaming Design on Students' Learning Achievements, Motivation, Behavioral Patterns, and Tendency Towards Critical Thinking and Problem Solving," British Journal of Educational Technology, vol. 48, no. 4, pp. 950-971, Jul. 2017.

[6] R. Kitchin, "Thinking Critically About and Researching Algorithms," Information Communication \& Society, vol. 20, no. 1, pp. 14-29, 2017.

[7] H. Lee et al., "Cooperation Begins: Encouraging Critical Thinking Skills Through Cooperative Reciprocity Using a Mobile Learning Game,” Computers \& Education, vol. 97, pp. 97-115, Jun. 2016.

[8] M. P. Shyshkina and U. P. Kohut, "The Use of the Cloud-Based Learning Component with the Maxima System for Teaching Operations Research,” Information Technologies and Learning Tools, vol. 57, no. 1, pp. 154-172, 2017.

[9] N. S. Stephenson and N. P. Sadler-McKnight, "Developing Critical Thinking Skills Using the Science Writing Heuristic in the Chemistry Laboratory," Chemistry Education Research and Practice, vol. 17, no. 1, pp. 72-79, 2016. 


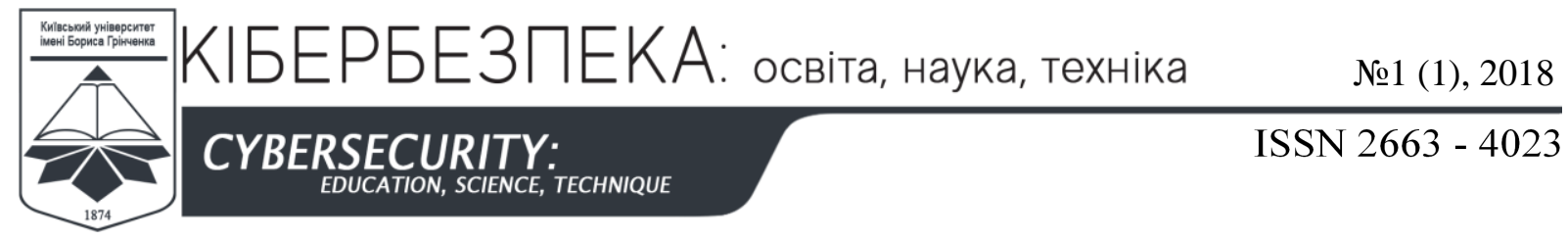

\title{
УДК 373.5:53
}

\section{Бодненко Дмитро Миколайович}

кандидат педагогічних наук, доцент кафедри комп’ютерних наук і математики

Київський університет імені Бориса Грінченка, м. Київ, Україна

OrcID: 0000-0001-9303-6587

d.bodnenko@kubg.edu.ua

\section{Остапенко Микита Володимирович}

аспірант кафедри кафедри комп'ютерних наук і математики

Київський університет імені Бориса Грінченка, м. Київ, Україна

OrcID: 0000-0002-4954-8179

m.oostapenko@kubg.edu.ua

\section{ЗАСТОСУВАННЯ НАВЧАЛЬНИХ ТЕХНОЛОГІЙ НА ОСНОВІ ОРГАНІЗАЦЇ̈ ДОСЛІДНИЦЬКОї ДІЯЛЬНОСТІ}

\begin{abstract}
Анотація. Основна мета дослідження полягає в розробці механізму організації науководослідної роботи студентів до оволодіння грамотністю ІКТ. У статті створено модель організації студентської науково-дослідної роботи у процесі навчання інформатичних дисциплін; сформовано алгоритм застосування хмарних технологій навчання в організації дослідницької роботи студентів історії; описані рекомендації щодо структури та змісту електронних навчальних матеріалів при вивченні хмарних технологій навчання (як частина навчального курсу в LMS Moodle). Наведено рекомендації, які можна окреслити на основі проведеного аналізу досвіду впровадження хмаро орієнтовних технологій навчання інформатичних дисциплін за різними спеціальностями: доцільно використовувати таблицю модель таблицю "Використання хмарних технологій навчання" з відповідною адаптацією до науково-педагогічної та матеріально-технічної база конкретного закладу освіти. Впровадження призначеної моделі сприяє: продуктивній діяльності студентів; автономії навчання та максимальному наближенню накопиченого досвіду до вимог ринку праці; формування активної позиції дослідників учасників проекту; формування критичного мислення учнів шляхом поетапної активації операцій мислення. Використання моделі має бути творчим у подоланні деяких негативних аспектів: розробити мотиваційний аспект залучення студентів до дослідницької діяльності; формувати визначення майбутньої дослідницької діяльності студента; максимізувати взаємодію науки з навчальним процесом та вимогами ринку праці; щоб подолати стереотип, що не всі студенти повинні бути залучені до наукової роботи.
\end{abstract}

Ключові слова: хмаро орієнтовані технології навчання; хмарне сервіси; матеріали електронного навчання; науково-дослідне дослідження; IКТ у сфері освіти; дидактика; процес формування компетенції; інформаційні технології навчання; методика викладання.

\section{REFERENCES}

[1] D. M. Bodnenko, "Cloud Oriented Technologies as a Factor of Research-Based Training," Information Technologies and Learning Tools, vol. 48, no. 4, pp. 122-139, 2015.

[2] A. Cimer and M. Timucin, "Content of an In-Service Training to Develop and Assess Activities Minding Critical Thinking," in World Conference on Learning, Teaching and Administration, vol. 9, p. 5, 2010. 
[3] G. A. Ferrer and A. Garcia-Barrera, "Evaluation of the Effectiveness of Flipped Classroom Videos," in 8th International Technology, Education and Development Conference (INTED), Valencia, Spain, pp. 2608-2613, 2014.

[4] D. F. Halpern, "Teaching Critical Thinking for Transfer Across Domains - Dispositions, Skills, Structure Training, and Metacognitive Monitoring," American Psychologist, vol. 53, no. 4, pp. 449-455, Apr. 1998.

[5] G. J. Hwang and C. H. Chen, "Influences of an Inquiry-Based Ubiquitous Gaming Design on Students' Learning Achievements, Motivation, Behavioral Patterns, and Tendency Towards Critical Thinking and Problem Solving," British Journal of Educational Technology, vol. 48, no. 4, pp. 950-971, Jul. 2017.

[6] R. Kitchin, "Thinking Critically About and Researching Algorithms," Information Communication \& Society, vol. 20, no. 1, pp. 14-29, 2017.

[7] H. Lee et al., "Cooperation Begins: Encouraging Critical Thinking Skills Through Cooperative Reciprocity Using a Mobile Learning Game," Computers \& Education, vol. 97, pp. 97-115, Jun. 2016.

[8] M. P. Shyshkina and U. P. Kohut, "The Use of the Cloud-Based Learning Component with the Maxima System for Teaching Operations Research,” Information Technologies and Learning Tools, vol. 57, no. 1, pp. 154-172, 2017.

[9] N. S. Stephenson and N. P. Sadler-McKnight, "Developing Critical Thinking Skills Using the Science Writing Heuristic in the Chemistry Laboratory," Chemistry Education Research and Practice, vol. 17, no. 1, pp. 72-79, 2016.

\section{(cc) BY-We-si}

This work is licensed under Creative Commons Attribution-NonCommercial-ShareAlike 4.0 International License. 